\title{
Chromium in urothelial carcinoma of the bladder
}

\author{
Tomasz Golabek ${ }^{1}$, Katarzyna Socha ${ }^{2}$, Jacek Kudelski ${ }^{3}$, Barbara Darewicz ${ }^{3}$, \\ Renata Markiewicz-Zukowska², Piotr Chlosta', Maria Borawska' \\ ${ }^{1}$ Department of Urology, Medical College, Jagiellonian University, Krakow, Poland \\ ${ }^{2}$ Department of Bromatology, Medical University, Bialystok, Poland \\ ${ }^{3}$ Department of Urology, Medical University, Bialystok, Poland
}

Golabek T, Socha K, Kudelski J, Darewicz B, Markiewicz-Zukowska R, Chlosta P, Borawska M. Chromium in urothelial carcinoma of the bladder. Ann Agric Environ Med. 2017; 24(4): 602-605. doi: 10.5604/12321966.1232760

\begin{abstract}
Ibstract
Introduction and objectives. Many epidemiological and experimental studies report a strong role of chemical carcinogens in the etiology of bladder cancer. However, the involvement of heavy metals in tumourigenesis of urothelial carcinoma of the bladder has been poorly investigated. Therefore, the aim of this study was to examine the relationship between chromium (Cr) and bladder cancer.

Materials and methods. Chromium concentration in two 36-sample series of bladder cancer tissue and sera from patients with this neoplasm were matched with those of a control group. The amount of trace elements in every tissue sample was determined using atomic absorption spectrometry. This was correlated with tumour stage.

Results. While the median chromium concentration levels reached statistically higher values in the bladder cancer tissue, compared with the non-cancer tissue $(99.632 \mathrm{ng} / \mathrm{g}$ and $33.144 \mathrm{ng} / \mathrm{g}$, respectively; $\mathrm{p}<0.001)$, the median Cr levels in the sera of the patients with this carcinoma showed no statistical difference when compared to those of the control group $(0.511 \mu \mathrm{g} / \mathrm{l}$ and $0.710 \mu \mathrm{g} / \mathrm{l}$, respectively; $\mathrm{p}=0.408$ ). The median levels of $\mathrm{Cr}$ in the bladder tissue, depending on the stage of the tumour, compared with the tissue without the neoplasm, observed the same relationship for both non-muscle invasive and muscleinvasive tumours $(p<0.001$ and $p<0.01$, respectively).

Conclusions. This study shows that patients with urothelial carcinoma of the bladder had higher tissue $\mathrm{Cr}$ levels than people without tumour, while no difference was found in the $\mathrm{Cr}$ serum levels between the two groups of patients under investigation.
\end{abstract}

\section{Key words}

chromium, bladder cancer, heavy metals

\section{INTRODUCTION}

There is an emerging understanding of toxic and carcinogenic effects of certain heavy metals and trace elements in both animals and humans [1-7]. Chromium $(\mathrm{Cr})$ is a known human carcinogen and has been hypothesized as a cause of several cancers, including leukaemia and neoplasms of lung, nose and nasal sinuses [8-10]. Moreover, there is epidemiological evidence suggesting that $\mathrm{Cr}$ is a plausible bladder carcinogen [11-14]. Additionally, higher Cr levels in the urine of people occupationally exposed to this element have been reported, further suggesting its possible contribution to lower urinary tract carcinogenesis [15]. Thus far, however, there has been no demonstrable direct evidence for the association of $\mathrm{Cr}$ with human urothelial carcinoma of the bladder.

In the presented study, the concentration of chromium in the tissue of bladder tumour was measured and compared with the content in non-cancerous tissue. In addition, the concentration of $\mathrm{Cr}$ in the sera of patients with bladder tumours were compared with control samples from patients with non-neoplasm- or non-heavy metal-related diseases of the urinary system. Finally, the resultant levels were evaluated, depending on the stage of the tumour.

Address for correspondence: Tomasz Golabek, Department of Urology, Medical College, Jagiellonian University, Krakow, Poland

E-mail: elementare@op.pl

Received: 24 November 2013; accepted: 29 July 2014; first published on January 2017

\section{MATERIALS AND METHOD}

The study was approved by the Medical Ethics Committee for Human Studies of the Medical University in Bialystok, Poland, and all procedures were performed in accordance with the Helsinki Declaration of 1975, as revised in 1983. The study was conducted on 36 patients with histologicallyproven urothelial bladder carcinoma, with no lymph node involvement or distant metastases. The patients were 30 men aged 41-88 (average 68.5 years) and 6 women aged 52-78 (average 67 years). Non-muscle invasive cancers (Tis - Ta - T1) occurred in 22 cases, and muscle-invasive tumours (T2 - T3 - T4) in 14 patients. The grade of histological malignancy, G1, G2 and G3, was found in 10, 13, and 10 patients, respectively, whereas in 3 patients it was not possible to establish with certainty the actual grade of malignancy.

The tumours were removed by transurethral resection (TURBT) in 29 patients and by cystectomy in 7 patients. Just after the bladder or the tumour itself had been removed, samples of $1 \mathrm{~g}$ of cancer tissue were taken and stored after being snap frozen in liquid nitrogen. Before bladder or tumour removal, three-milliliter samples of venous blood were collected from the basilic vein using Vacutainer vacuum sets.

The control material consisted of 15 one-gram samples of bladder tissue taken from gender-and-age-matched individuals who had died from trauma $(n=15)$. Samples were taken during autopsy from 12 male cadavers aged 54-77 
(average 64 years) and 3 females aged 57-76 (average 65.5 years).

Next, 15 three-millilitre samples of venous blood from the corresponding gender-and-age-matched patients, who were in fasting states with non-neoplasm or trace elements-related diseases of the urinary system (1 woman with benign pelvicureteric junction obstruction, 3 with stress incontinence, 3 men with scrotal injury, 3 with renal injury, 2 with benign urethral stricture and 3 with hydrocele), were collected in Vacutainer vacuum sets and used in the control group. There were 11 samples taken from male patients aged 43-86 (average 67 ), and 4 from females aged 52-78 (average 67.5 years). There was no difference between the socio-economic status of the cases and controls. Neither group had occupational exposure to chromium.

Before analysis, the samples were mineralized in concentrated nitric acid (V) in a UniClever closed microwave system manufactured by Plazmatronika. The mineralization products were quantitatively transferred into polypropylene scintillation vessels. $\mathrm{Cr}$ was quantitatively determined directly in the sera samples diluted with $0,2 \%$ Triton X-100. The levels of Cr concentration were analyzed by the atomic absorption spectrometry technique with the Zeeman background correction on a Hitachi Z-5000 spectrometer. The $\mathrm{Cr}$ content was calculated using readings on a standardisation curve formed by recording differences in absorbance and element concentration. The accuracy of the $\mathrm{Cr}$ determination method was verified using the following certified standard materials: Seronorm 404108 for the whole blood and BCR 184 for bovine muscle. Accuracy (i.e. \% of error) and coefficient of variation were calculated for the certified standards under investigation. The samples were evaluated in the Department of Bromatology of the Medical University in Bialystok, which is involved in a programme of intra-laboratory comparative analysis of elements, organized by the Institute of Chemistry and Nuclear Techniques, and the State Institution of Sanitation in Poland.

Since data in the studied group was not distributed in a Gaussian manner, the Mann-Whitney U test was used. A p value of $<0.05$ was considered statistically significant. The Statistical Package for the Social Sciences (SPSS) was used for all statistical analyses.

\section{RESULTS}

Median values of $\mathrm{Cr}$, determined in the bladder cancer tissue and sera of the patients with bladder tumour and the control group, are shown in Table 1. Figures 1-2 present Cr bladder tissue and serum concentration distribution of patients with bladder cancer and controls.

Table 1. Bladder tissue and serum chromium concentrations in patients with bladder cancer vs. controls

\begin{tabular}{llccccc}
\hline Group & & $\mathrm{n}$ & $\mathrm{Q} 1$ & Median & $\mathrm{Q} 3$ & $\mathrm{p}$ \\
\hline Crserum, & bladder cancer cases & 36 & 0.353 & 0.511 & 0.920 & \multirow{2}{*}{0.408} \\
\cline { 2 - 6 }$\mu \mathrm{g} / \mathrm{l}$ & controls & 15 & 0.388 & 0.710 & 0.942 & \\
\hline $\begin{array}{l}\text { Cr bladder } \\
\text { tissue, ng/g }\end{array}$ & bladder cancer cases & 36 & 51.045 & 99.632 & 186.582 & \multirow{2}{*}{$0.001^{*}$} \\
\cline { 2 - 6 } & controls & 15 & 24.764 & 33.144 & 42.605 & \\
\hline
\end{tabular}

$\mathrm{Cr}$ - chromium; * - statistically significant; $\mathrm{n}$ - number of samples; Q1 - lower quartile; Q3 upper quartile

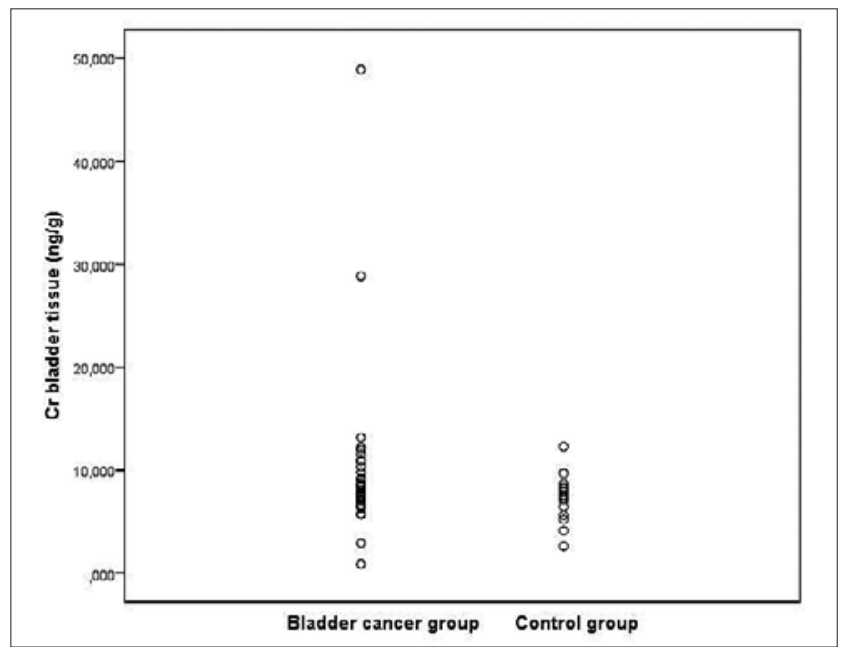

Figure 1. Chromium $(\mathrm{Cr})$ distribution in bladder tissue of patients with bladder cancer and control group

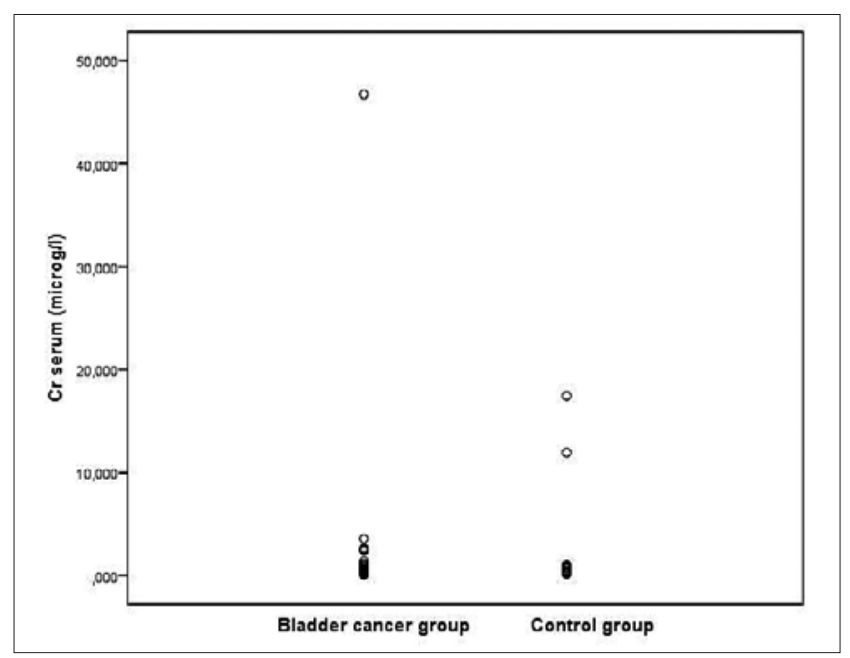

Figure 2. Chromium ( $\mathrm{Cr}$ ) distribution in sera of patients with bladder cancer and control group

The median value of $\mathrm{Cr}$ concentration in the bladder cancer tissue and in the non-cancer tissue was $99.632 \mathrm{ng} / \mathrm{g}$ and $33.144 \mathrm{ng} / \mathrm{g}$, respectively. This increase in Cr concentration in cancer tissue was statistically significant $(\mathrm{p}<0.001)$. There was no significant difference in the serum Cr levels between the groups $(0.511 \mu \mathrm{g} / \mathrm{l}$ and $0.710 \mu \mathrm{g} / \mathrm{l}$, respectively; $\mathrm{p}=0.408)$. Moreover, tissue and serum Cr levels were calculated for the two tumour stage groups, (one with non-muscle invasive and the other with muscle invasive cancers). When processed by the non-parametric Mann-Whitney U test, the results showed that the median levels of $\mathrm{Cr}$ in the bladder tissue, depending on the stage of the tumour, were significantly higher for both non-muscle invasive and muscle-invasive tumours, compared with the tissue without the neoplasm $(\mathrm{p}<0.001$ and $\mathrm{p}<0.01$, respectively). There was no marked difference in the Cr serum levels, between people with urothelial carcinoma of the bladder and the controls when analysed by the two tumour stage groups (Tab. 2). 
Table 2. Bladder tissue and serum chromium concentrations in patients with non-muscle invasive vs. muscle invasive bladder cancer

\begin{tabular}{lllcccc}
\hline Group & & $\mathrm{n}$ & $\mathrm{Q} 1$ & Median & $\mathrm{Q} 3$ & $\mathrm{p}$ (vs. control) \\
\hline \multirow{2}{*}{ Cr serum, $\mu \mathrm{g} / \mathrm{l}$} & $\mathrm{Tis+Ta+T1}$ & 22 & 0.375 & 0.522 & 1.212 & 0.680 \\
\cline { 2 - 6 } & $\mathrm{T} 2+\mathrm{T} 3+\mathrm{T} 4$ & 14 & 0.345 & 0.411 & 0.683 & \multirow{2}{*}{0.270} \\
\cline { 2 - 5 } & controls & 15 & 0.388 & 0.710 & 0.942 & \\
\hline \multirow{3}{*}{$\begin{array}{l}\text { Cr bladder } \\
\text { tissue, ng/g }\end{array}$} & Tis+Ta+T1 & 22 & 63.785 & 106.28 & 175.367 & $0.001^{*}$ \\
\cline { 2 - 5 } & T2+T3+T4 & 14 & 27.661 & 69.184 & 251.33 & \multirow{2}{*}{$0.01^{*}$} \\
\cline { 2 - 5 } & controls & 15 & 24.764 & 33.144 & 42.605 & \\
\hline
\end{tabular}

$\mathrm{Cr}$ - chromium; $\mathrm{n}$ - number of samples; Q1 - lower quartile; Q3 - upper quartile; vs. - versus; * - statistically significant

\section{DISCUSSION}

In the study, a statistically significant elevation of tissue chromium levels was observed in patients with bladder cancer, and no difference in the serum Cr levels between the two groups of patients under investigation. To the best of the authors' knowledge, there has been no previous report on $\mathrm{Cr}$ concentration levels in the bladder tissue and sera of patients with bladder cancer and controls. However, several epidemiological studies have suggested an association between $\mathrm{Cr}$ exposure and the risk of urinary bladder cancer [11-14]. Kutze et al. in their study, found a significantly increased probability of developing lower urinary tract urothelial tumours in patients occupationally exposed to chromium/ chromate [13]. The observed relationship was confirmed in a multivariate logistic regression analysis, which showed a significant contribution of $\mathrm{Cr}$ to the risk of bladder cancer. These observations were further corroborated by the findings from the matched case-control study of 431patients with urothelial cancer of the lower urinary tract from Northern Germany [12]. In this report, occupational exposure to chromium/chromate was associated with the increased risk of BC (odds ratio of 1.77; 95 per cent confidence interval $=1.06-2.97$ ). Interesting data is provided by Stamatiou et al. who followed 45 patients with non-muscle invasive bladder cancer for a period of three years [14]. The authors observed an exceptionally high recurrence rate of BC (42\%) in their sample, which occurred within a three months interval. Although they did not directly assessed the levels of $\mathrm{Cr}$ in the patients' tissues, the authors hypothesized that the reported unusually frequent reappearance of bladder cancer in that group of patients could have been associated with the consumption of contaminated tap water containing large amounts of hexavalent chromium.

The aforementioned observations linking $\mathrm{Cr}$ to bladder cancer could be related to the fact that the urinary system is very much involved in the $\mathrm{Cr}$ removal process from the human organism, as excretion of this element occurs predominantly through urine [16]. Thus, whenever this element is present in urine, it may directly act on the urothelium, especially inside the bladder, which functions as a temporary reservoir for urine and, as such, is exposed to Cr action for a longer time. Of added interest is evidence suggesting that urinary Cr levels increase with time of occupational exposure, which potentially could increase the risk for developing a bladder neoplasm $[15,17]$.
The International Agency for Research on Cancers has classified Cr (VI) as Group I (human carcinogen), whereas Cr (III) as Group III (non-carcinogenic to human) [8]. Similarly, The United States Environment Protection Agency (EPA) has classified $\mathrm{Cr}$ in +6 oxidation state as Group A, a known human carcinogen, and $\mathrm{Cr}$ in +3 oxidation state as Group D (non-carcinogenic to humans) [18]. The mechanisms involved in chromium-induced carcinogenesis are not, however, completely understood. Depending on the oxidation state of the chromium and presence of cellular reductants, it causes a wide variety of DNA lesions including Cr-DNA adducts, DNAprotein crosslinks, DNA-DNA-crosslinks, lipid peroxidation and oxidative damage $[19,20]$. Although evidence for $\mathrm{Cr}(\mathrm{VI})$ induced carcinogenicity and mutagenicity has been well recognised, the capability of $\mathrm{Cr}$ (III), and in other oxidation states to produce free radicals in the presence of certain ligands, have been learnt only recently [21-24].

The exact pathological mechanisms for alterations in $\mathrm{Cr}$ tissue levels in patients with bladder carcinoma remain unclear. For the time being, it is difficult to say whether observed differences in levels of this heavy metal in tissues are the causative factors or the results of the neoplastic process. However, in the presented study, occupational exposure was ruled out as a cause for element alterations in both the $\mathrm{BC}$ patients and controls.

The current study found no difference in the serum $\mathrm{Cr}$ levels between the two groups of patients under investigation. This observation can be attributed to the fact that serum $\mathrm{Cr}$ concentration reflects current exposure rather than wholebody burdens [15]. Therefore, absence of difference in $\mathrm{Cr}$ serum levels between subjects with bladder cancer and controls provides an indirect evidence that both groups of people had similar exposure to chromium.

North-Eastern Poland is regarded as un unpolluted region and has been found to have low environmental contamination with $\mathrm{Cr}$ [25].This is mainly due to a lack of anthropogenic sources of heavy metals, such as industrial waste, mining or smelting activity. Automobile exhausts, municipal effluents and smoking are the major sources of $\mathrm{Cr}$ in this area.

\section{CONCLUSIONS}

Patients with urothelial carcinoma of the urinary bladder show alterations in the Cr levels in tissue suggesting an association between this cancer and the heavy metal. Higher Cr levels may play a role in the induction and development of the bladder tumour, or may be the result of the neoplastic process. Further studies should assess the biological significance of these parameters and their relationship with other contributing neoplastic factors.

\section{Conflict of interest}

The authors declare that they have no conflict of interest.

\section{REFERENCES}

1. Golabek T, Darewicz B, Borawska M, Markiewicz R, Socha K, Kudelski $\mathrm{J}:$ Lead concentration in the bladder tissue and blood of patients with bladder cancer. Scand J Urol Nephrol 2009; 25:1-4.

2. Golabek T, Darewicz B, Borawska M, Socha K, Markiewicz R, Kudelski J.Copper, zinc, and $\mathrm{Cu} / \mathrm{Zn}$ ratio in transitional cell carcinoma of the bladder.Urol Int. 2012; 89(3):342-7. 
3. Szkup-Jabłońska M, Karakiewicz B, Grochans E, Jurczak A, NowakStarz G, Rotter I, Prokopowicz A.Effects of blood lead and cadmium levels on the functioning of children with behaviour disorders in the family environment. Ann Agric Environ Med. 2012; 19(2):241-6.

4. Jurczak A, Brodowski J, Grochans E, Karakiewicz B, Szkup-Jabłońska M, Wieder-Huszla S, Mroczek B, Włoszczak-Szubzda A, Grzywacz AEffect of menopausal hormone therapy on the levels of magnesium zinc, lead and cadmium in post-menopausal women. Ann Agric Environ Med. 2013; 20(1):147-51.

5. Strecker D, Mierzecki A, Radomska K.Copper levels in patients with rheumatoid arthritis.Ann Agric Environ Med. 2013 Jun 9;20(2):312-6.

6. Jenerowicz D, Silny W, Dańczak-Pazdrowska A, Polańska A, OsmolaMańkowska A, Olek-Hrab K.Environmental factors and allergic diseases.Ann Agric Environ Med. 2012; 19(3):475-81.

7. Golabek T, Darewicz B, Kudelski J, Socha K, Markiewicz-Zukowska R, Chlosta P, Okoń K, Borawska M.Cadmium in urothelial carcinoma of the bladder.Pol J Pathol 2014; 65 (1): 55-59.

8. Chromium, nickel and welding.IARC Monogr Eval Carcinog Risks Hum. 1990;49:1-648.

9. Durant JL, Chen J, Hemond HF, Thilly WG.Elevated incidence of childhood leukemia in Woburn, Massachusetts: NIEHS Superfund Basic Research Program searches for causes.Environ Health Perspect. 1995 Sep;103 Suppl 6:93-8.

10. Cole P, Rodu B.Epidemiologic studies of chrome and cancer mortality: a series of meta-analyses. Regul Toxicol Pharmacol. 2005 Dec;43(3):22531.

11. Henry SA, Kennaway NM, Kennaway EL.The Incidence of Cancer of the Bladder and Prostate in Certain Occupations. J Hyg (Lond). 1931 Apr;31(2):125-37.

12. Claude J, Kunze E, Frentzel-Beyme R, Paczkowski K, Schneider J, Schubert H.Life-style and occupational risk factors in cancer of the lower urinary tract. Am J Epidemiol. 1986 Oct;124(4):578-89.

13. Kunze E, Chang-Claude J, Frentzel-Beyme R.Etiology, pathogenesis and epidemiology or urothelial tumors. Verh Dtsch Ges Pathol. 1993;77:147-56

14. Stamatiou K.Hexavalent chromium and bladder cancer risk.Actas Urol Esp. 2012 Mar;36(3):199-200.

15. Lukanova A, Toniolo P, Zhitkovich A, Nikolova V, Panev T, Popov T, Taioli E, Costa M.Occupational exposure to $\mathrm{Cr}(\mathrm{VI})$ : comparison between chromium levels in lymphocytes, erythrocytes, and urine. Int Arch Occup Environ Health. 1996;69(1):39-44.

16. Agency for Toxic Substances and Disease Registry (ATSDR). 2012. Toxicological profile for Chromium. Atlanta, GA: U.S. Department of Health and Human Services, Public Health Service. Available at: http://www.atsdr.cdc.gov/toxprofiles/tp7.pdf.

17. Rahkonen E, Junttila ML, Kalliomäki PL, Olkinouora M, Koponen M, Kalliomäki K.Evaluation of biological monitoring among stainless steel welders. Int Arch Occup Environ Health. 1983; 52(3):243-55.

18. U.S. EPA, 1998. Integrated Risk Information Service (IRIS) assessment for hexavalent chromium.Available at:http://www.epa.gov/ncea/iris/ subst/0144.htm.

19. Kasprzak KS.Possible role of oxidative damage in metal-induced carcinogenesis. Cancer Invest. 1995; 13(4):411-30.

20. Bagchi D, Hassoun EA, Bagchi M, Muldoon DF, Stohs SJ.Oxidative stress induced by chronic administration of sodium dichromate $[\mathrm{Cr}(\mathrm{VI})]$ to rats.Comp Biochem Physiol C Pharmacol Toxicol Endocrinol. 1995 Mar;110(3):281-7.

21. Zhitkovich A, Song Y, Quievryn G, Voitkun V.Non-oxidative mechanisms are responsible for the induction of mutagenesis by reduction of $\mathrm{Cr}(\mathrm{VI})$ with cysteine: role of ternary DNA adducts in Cr(III)-dependent mutagenesis. Biochemistry. 2001 Jan 16;40(2):54960.

22. Quievryn G, Peterson E, Messer J, Zhitkovich A.Genotoxicity and mutagenicity of chromium(VI)/ascorbate-generated DNA adducts in human and bacterial cells. Biochemistry. 2003 Feb 4;42(4):1062-70.

23. Ozawa T, Hanaki A.Spin-trapping studies on the reactions of $\mathrm{Cr}$ (III) with hydrogen peroxide in the presence of biological reductants: is Cr(III) non-toxic?Biochem Int. 1990 Oct;22(2):343-52.

24. Sugden KD, Geer RD, Rogers SJOxygen radical-mediated DNA damage by redox-active $\mathrm{Cr}$ (III) complexes. Biochemistry. 1992 Nov 24;31(46):11626-31.

25. Małecki JJ, Gruszczyński T. Mobility of chromium in the Krynka Valley artesian structure in the light of hydrodynamical field modeling. Biuletyn Panstwowego Instytutu Geologicznego 2012; 452: 167-180. Available at: https://www.pgi.gov.pl/en/dokumenty-in/doc_view/1654biul452maleckipdf-.html. 